\title{
TATALAKSANA PEMELIHARAAN TERNAK KERBAU BELANG DI KECAMATAN MAMASA KABUPATEN MAMASA PROVINSI SULAWESI BARAT
}

\author{
John E.G. Rompis*), Jantje F. Paat*), Martha M. Kawatu*), dan \\ Demmalona**) \\ Fakultas Peternakan Universitas Sam Ratulangi Manado, 95115. \\ email: jegronne@yahoo.co.id
}

\begin{abstract}
ABSTRAK
Penelitian ini dilakukan untuk mengetahui perilaku masyarakat peternak di Kecamatan Mamasa, Kabupaten Mamasa, Profinsi Sulawesi Barat dalam pemeliharaan ternak kerbau belang. Penelitian ini dilakukan pada bulan Juni sampai Juli 2010, menggunakan metode survey melibatkan 23 responden peternak kerbau belang dari 4 desa yang ditentukan secara purposive sampling. Data primer diperoleh langsung dari responden melalui wawancara dan observasi langsung di lapangan, serta data sekunder diperoleh dari instansi pemerintah dan swasta yang ada hubungannya dengan penelitian ini. Untuk menggambarkan kondisi ternak, dilakukan pengamatan jenis, pakan dan tata laksana pemeliharaannya. Hasil penelitian menunjukkan bahwa lebih dari setelah peternak $(52 \%)$ mendapatkan ternak dari warisan orangtuanya. Untuk menyeleksi ternak, peternak melakukan pengamatan terhadap cacat fisik, proporsi tubuh, keaktifan gerak, bulu mengkilap dan organ genital yang normal. Pemberian pakan dilakukan baik pada saat ternak berada di kandang maupun saat digembalakan. Sebanyak $60.9 \%$ peternakan memberi pakan berupa rumput gajah, rumput lokal serta garam. Sebagian peternak tidak memiliki kandang yang baik, nereka membuatnya dengan menggunakan materi lokal dengan peralatan seadanya. Hasil penelitian ini
\end{abstract}

- Jurusan Produksi Ternak

- Alumni Fakultas Peternakan Unsrat menunjukkan bahwa peternak di daerah ini masih menggunakan sistem pemeliharaan ternak secara tradisional.

\section{Kata Kunci:Tatalaksana kerbau belang, Kabupaten Mamasa.}

\section{ABSTRACT}

THE MANAGEMENT OF KERBAU BELANGIN THE MAMASA'S DISTRICT OF MAMASA'S REGENCY WEST SULAWESI PROVINCE.This research was done to analyse behavior sociaty of Mamasa's district Mamasa's regency West Sulawesi Province in preserve the management of kerbau belang. This research was conducted in June until July 2010. Research was applied using survey methode involving 23 respondence of kerbau belang farmers randomly chosing from 4 purposive sampling villages. Primer data were directly collected by using questionaire, while secondary data was obtain from intitusions involved in this research. Descriptive analysis of breed, feed, and farm engineering was applied to describe farmer of animal condition. Result showed that more than half farmer $(52 \%)$ deriving breed from parent inheritance. Insignificant part by from another farmer. Breed selection by farmer with observed the bull were not physical defect, body proportion, moving aktive, lustrous body hair, and normal genital organ. The feeding system do in the pen or the pasture with kid of elephant grass, local grass, and salt (60.9\%), and not leasure. 
Best part of farmers not own pen, if be present, they were make the pen with local material, and pen equiptment was patch up. Sanitary pen non observance. From this research have as a conclusion that the kerbau belang farmers on this regency were apply traditional system.

\section{Keywords: Kerbau belang manage- ment, Mamasa's regency West Sulawesi.}

\section{PENDAHULUAN}

Salah satu kebijakan yang dicanangkan dalam pembangunan ekonomi masyarakat Kabupaten Mamasa, khususnya di Kecamatan Mamasa adalahPembangunan peternakan. Tujuan pembangunan peternakan diarahkan pada percepatan peningkatan populasi dan produksi ternak dalam rangka memenuhi kebutuhan masyarakat akan protein hewani. Hal ini sangat menunjang karena ketersediaan lahan yang luas, serta ketersediaan pakan yang cukup. Di Kecamatan Mamasa, kerbau belang merupakan objek penting dalam acara adat istiadat penduduk setempat, misalnya dalam acara pernikahan (rambu tu'ka) dan kematian (rambu solo'). Kerbau atau bahasa setempat disebut tedong atau karembau, memainkan peranan yang sangat penting dalam kehidupan sosial masyarakat Toraja serta etnis lain yang tinggal di daerah sekitar Toraja. Menurut Matandung dkk. (2007), selain menjadi alat transaksi (misalnya dalam jual beli tanah, serta warisan) kerbau juga dipakai sebagai persembahan dalam upacara rambu solo'dan rambu tu'ka masyarakat Toraja. Dengan demikian status sosial dari masyarakat setempat dapat dilihat dari banyaknya kerbau belang yang disembelih pada acara pernikahan atau kematian. Seekor kerbau belang dewasa harganya bisa mencapai puluhan juta bahkan ratusan juta rupiah. Kerbau belang merupakan jenis ternak kerbau yang kulitnya berwarna kombinasi merah muda albino dan hitam kelabu. Kerbau ini juga dapat menghasilkan susu yang dapat dikonsumsi oleh masyarakat sebagai minuman yang meningkatkan asupan nutrisi keluarga. Seekor kerbau bisa menghasilkan tiga liter susu per hari. Ini menunjukkan bahwa usaha ternak kerbau belang selain menguntungkan karena bernilai jual tinggi, juga memberikan keuntungan lain bagi keluarga peternak yaitu peningkatan gizi dan penyediaan pupuk untuk kebunnya. Kerbau belang atau dalam bahasa setempat disebut tedong doti atau tedong bonga sangat mahal harganya, karena diyakini sebagai kerbau khas yang hanya ditemukan di Toraja Mamasa. Oleh karena itu manajemen pemeliharaan ternak kerbau belang perlu diperhatikan.

Pemeliharaan ternak kerbau belang khususnya di Kecamatan Mamasa masih bersifat tradisional, oleh sebab itu perlu adanya tatalaksana pemeliharaan yang baik. Tatalaksana pemeliharaan yang baik dapat mempertahankan dan memperbaiki bahkan akan lebih meningkatkan nilai jual dari ternak tersebut sehingga pendapatan dari petani peternak menjadi lebih baik.

\section{MATERI DAN METODE PENELITIAN}

Penelitian ini dilaksanakan di Kecamatan Mamasa Kabupaten Mamasa Provinsi Sulawesi Barat, 
pada bulan Juni sampai dengan Juli 2010. Metode penelitian adalah survei dengan mengambil sampel dari satu populasi dengan menggunakan daftar pertanyaan sebagai alat pengumpul data yang pokok (Singarimbun dan Efendi, 1089). Penentuan lokasi penelitian dilakukan dengan cara purposive sampling, yaitu keseluruhan sampel dari desa sampel di Kecamatan mamasa berdasarkan kesengajaan dan atas pertimbangan-pertimbangan tertentu (Arikunto, 1992). Sebagai objek penelitian adalah petani peternak. Untuk dipilih sebagai responden peternak harus memiliki jumlah ternak minimal 5 ekor dan pemeliharaan dilakukan minimal 5 tahun terakhir. Data primer diperoleh langsung dari responden melalui wawancara dan observasi langsung di lapangan, serta data sekunder diperoleh dari instansi pemerintah dan swasta yang ada hubungannya dengan penelitian ini. Data ditabulasi sesuai dengan informasi atau himpunan fakta melalui survei di lapangan, selanjutnya diprosentasekan sesuai data yang ada (Arikunto, 1992).

Variabel yang diamati dalam penelitian ini adalah: 1). Bibit (cara memperoleh bibit, cara mengetahui bibit jantan yang baik, cara mengetahui bibit betina yang baik, 2). Makanan (sistem pemberian makanan, jenis makanan, dan cara pemberian makanan), 3). Perkandangan (sistem perkandangan, keadaan kandang, pemakaian kandang dan sanitasi kandang), 4). Penyakit (sistem pengontrolan penyakit, tindakan pencegahan, tindakan pengobatan, cara memperoleh obat-obatan), dan 5). Reproduksi (sistem perkawinan, umur pertama dikawinkan, cara mengetahui ternak betina sudah dapat dikawinkan, tanda-tanda ternak birahi, umur maksimal ternak jantan dikawinkan serta umur maksimal ternak betina dikawinkan).

\section{HASIL DAN PEMBAHASAN}

\section{Keadaan Umum Ternak di Kecamatan Mamasa.}

Pada sektor pertanian, sub sektor peternakan, usaha pemeliharaan ternak yang dikembangkan di Kecamatan Mamasa meliputi ternak kerbau, sapi, kuda, babi, kambing, ayam buras dan ternak itik. Populasi ternak dan jumlah populasi kerbau serta ternak besar lainnya berdasarkan desa sampel di Kecamatan Mamasa dapat dilihat pada Tabel 1 dan 2.

\section{Tatalaksana Pemeliharaan Ternak Kerbau Belang}

Faktor Bibit.

Data cara pemilihan bibit ternak kerbau belang oleh peternak (responden) di Kecamatan Mamasa berdasarkan hasil penelitian ini dapat dilihat pada Tabel 3.Persentase cara pemilihan bibit ternak kerbau belang oleh peternak di Kecamatan Mamasa menunjukkan bahwa 23 peternak memperoleh bibit dari warisan orang tua $(52,2 \%)$, dan yang dibeli oleh peternak (47,8\%). Hal tersebut memperlihatkan bahwa petani peternak kerbau belang yang ada bersifat turun temurun. Untuk mengetahui bibit jantan yang baik, $65,2 \%$ peternakan menyatakan bahwa memilih ternak yang tidak cacat, badan besar, aktif bergerak, bulu mengkilap serta testis normal; 56,5\% peternak memilih bibit ternak yang tidak cacat, badan besar, tanduk besar 
serta bentuk corak belang dan sebanyak $34,8 \%$ menyatakan badan besar serta bulu mengkilap. Demikian halnya dengan kriteria pemilihan ternak betina, akan tetapi kriteria dengan melihat factor bentuk corak belang pada bulu lebih dominan terhadap ternak jantan dibandingkan dengan ternak betina.

Standar mutu untuk menjamin produk ternak kerbau diperlukan persyaratan teknis secara umum ialah kerbau bibit harus sehat dan bebas dari segala cacat fisik seperti cacat mata, tanduk patah, pincang, lumpuh kaki dan kuku abnormal, serta tidak terdapat kelainan tulang atau cacat lainnya (Apriantono (2006). Selanjutnya dikatakan bahwa untuk memilih kerbau betina harus bebas dari cacat alat reproduksi, ambing abnormal serta tidak menunjukkan kemandulan, demikian halnya dengan kerbau bibit jantan harus tidak menderita cacat pada alat kelaminnya.
Faktor bibit dalam sistem pemeliharaan ternak kerbau belang masih kurang baik oleh karena sumber perolehan bibit dari warisan orang tua tanpa melihat kriteria pemilihan bibit yang baik. Hal ini dapat terjadi karena ikatan adat istiadat yang kuat dalam mempertahankan peninggalan orang tua dan juga kurangnya bimbingan dari instansi terkait, sehingga pengetahuan peternak terhadap sistem pemilihan bibit sangat rendah. Hal ini dapat pula mempengaruhi sistem pemeliharaan ternak kerbau belang, karena bibit memegang peranan penting dalam menumbuhkembangkan usaha peternakan.

\section{Makanan.}

Data hasil penelitian mengenai teknis pemberian pakan pada kerbau belang di Kecamatan Mamasa ditunjukkan pada tabel 4.

Tabel 1. Populasi Ternak di Kecamatan Mamasa tahun 2006-2009

\begin{tabular}{ccccc}
\hline \multirow{2}{*}{ Jenis Ternak } & \multicolumn{4}{c}{ Jumlah (ekor) } \\
\cline { 2 - 5 } & $\mathbf{2 0 0 6}$ & $\mathbf{2 0 0 7}$ & $\mathbf{2 0 0 8}$ & $\mathbf{2 0 0 9}$ \\
\hline Kerbau & 4790 & 4881 & 5264 & 5903 \\
\hline Sapi & 1490 & 1523 & 1866 & 2219 \\
\hline Kuda & 1993 & 2027 & 1968 & 2080 \\
\hline Kambing & 272 & 291 & 333 & 349 \\
\hline Babi & 33543 & 41321 & 32731 & 38272 \\
\hline Ayam Buras & 593 & 700 & 121206 & 103610 \\
\hline Ayam Ras & 1614 & 1980 & 7516 & 4885 \\
\hline Itik & 4075 & 4085 & 14312 & 11696 \\
\hline
\end{tabular}

Sumber: Anonimous, (2009). 
Tabel 2. Jumlah Populasi Ternak Kerbau Belang dan Ternak Besar Lainnya pada Desa Sampel di Kecamatan Mamasa pada Tahun 2009.

\begin{tabular}{|c|c|c|c|c|c|}
\hline \multirow{2}{*}{$\begin{array}{c}\text { Jenis } \\
\text { Ternak }\end{array}$} & \multicolumn{4}{|c|}{ Desa } & \multirow{2}{*}{ Jumlah } \\
\hline & Lemsa & Lambanan & Tondokbakaru & Ramsar & \\
\hline $\begin{array}{l}\text { Kerbau } \\
\text { Belang }\end{array}$ & 83 & 97 & 75 & 70 & 525 \\
\hline Sapi & 2 & 3 & 22 & 4 & 31 \\
\hline Kuda & 7 & 6 & 117 & 53 & 183 \\
\hline
\end{tabular}

Sumber: Anonimous (2009).

Tabel 3. Persentase Cara Pemilihan Bibit oleh Peternak Kerbau Belang di Kecamatan Mamasa.

\begin{tabular}{|c|c|c|c|}
\hline No. & Uraian & $\begin{array}{c}\text { Jumlah } \\
\text { Responden }\end{array}$ & Persentase \\
\hline \multirow[t]{5}{*}{1.} & Asal Bibit: & & \\
\hline & $\begin{array}{l}\text { - Diperoleh dari Dinas Peternakan (bantuan } \\
\text { pemerintah) }\end{array}$ & 0 & 0 \\
\hline & - Dibeli dari peternak lain & 11 & 47,8 \\
\hline & - Pemberian orang tua & 12 & 52,2 \\
\hline & - Diperoleh dari peternakan swasta & 0 & 0 \\
\hline \multirow[t]{6}{*}{2.} & Cara Melihat Bibit Jantan yang Baik: & & \\
\hline & $\begin{array}{l}\text { Tidak cacat, aktif bergerak, buu mengkilap, } \\
\text { testes yang normal. }\end{array}$ & 8 & 34,8 \\
\hline & - $\quad$ Badan besar, kaki lurus dan kuat & 0 & 0 \\
\hline & - Hanya melihat bentuk tanduk & 0 & 0 \\
\hline & - Tidak melihat keadaan atau kondisi ternak & 0 & 0 \\
\hline & $\begin{array}{l}\text { - Tidak cacat, badan besar, tanduk besar, bentuk } \\
\text { corak belang }\end{array}$ & 15 & 65,2 \\
\hline \multirow[t]{5}{*}{3.} & $\begin{array}{l}\text { Cara Melihat Betina yang Baik: } \\
\text { - Tidak cacat, aktif bergerak, kepala selalu tegak, } \\
\text { bulu bersih dan mengkilap, mata bercahaya, } \\
\text { mempunyai ambing yang normal dan tidak } \\
\text { terjadi infeksi, alat kelamin normal, kaki lurus } \\
\text { dan kuat. }\end{array}$ & 10 & 43,5 \\
\hline & - $\quad$ Tanduk yang besar & 0 & 0 \\
\hline & - Tidak melihat keadaan atau kondisi ternak & 0 & 0 \\
\hline & $\begin{array}{l}\text { - Badan tidak terlalu gemuk, kaki lurus, aktif } \\
\text { bergerak }\end{array}$ & 0 & 0 \\
\hline & $\begin{array}{l}\text { - Tidak cacat, badan besar, tanduk besar, bulu } \\
\text { mengkilap }\end{array}$ & 13 & 56,5 \\
\hline
\end{tabular}


Tabel 4. Teknis Pemberian Pakan pada Ternak Kerbau Belang di Kecamatan Mamasa.

\begin{tabular}{|c|c|c|c|}
\hline No. & Uraian & $\begin{array}{c}\text { Jumlah } \\
\text { Responden }\end{array}$ & Persentase \\
\hline \multirow[t]{5}{*}{1.} & Sistem pemberian pakan: & & \\
\hline & $\begin{array}{l}\text { Diberikan dalam kandang sesuai dengan } \\
\text { kebutuhan ternak }\end{array}$ & 0 & 0 \\
\hline & $\begin{array}{l}\text { Diberikan sebagian dalam kandang dan di padang } \\
\text { penggembalaan }\end{array}$ & 12 & 52,2 \\
\hline & - Diberikan di padang penggembalaan & 8 & 34,8 \\
\hline & - Dibiarkan bebas mencari makanannya sendiri & 3 & 13,0 \\
\hline \multirow[t]{8}{*}{2.} & Jenis makanan yang diberikan: & & \\
\hline & - Rumput potong dan konsentrat & 0 & 0 \\
\hline & - Rumput lapangan dan leguminosa & 0 & 0 \\
\hline & - Rumput lapangan saja & 0 & 0 \\
\hline & $\begin{array}{l}\text { - Rumput gajah, rumput-rumputan }+ \text { konsentrat }+ \\
\text { garam }\end{array}$ & 3 & 13,0 \\
\hline & - Rumput gajah, rumput-rumputan + garam & 14 & 60,9 \\
\hline & - Rumput-rumputan (tidak diperhatian) + garam & 6 & 26,1 \\
\hline & - Tidak memperhatikan & 0 & 0 \\
\hline \multirow[t]{6}{*}{3.} & Makanan yang diberikan: & & \\
\hline & - Selalu ditimbang & 0 & 0 \\
\hline & - Ditaksir & 0 & 0 \\
\hline & - $\quad$ Kadang ditaksir, kadang ditimbang & 0 & 0 \\
\hline & - $\quad$ Tidak ditimbang & 0 & 0 \\
\hline & - $\quad$ Tidak diukur & 23 & 100 \\
\hline
\end{tabular}

Sistem pemberian pakan yang dilakukan oleh peternak, lebih dari $50 \%$ peternak memberikan pakan pada saat dikandangkan maupun di padang penggembalaan $\quad(52,2 \%), \quad 34,8 \%$ memberikan pada saat ternak digembalakan serta hanya $13 \%$ membiarkan ternaknya Fungsi air garam adalah untuk merangsang agar ternak tersebut menghabiskan makanan yang diberikan. Sebanyak $26,1 \%$ peternak memberikan rumputrumputan yang ada dan diberi air garam, 13,0\% peternak memberikan rumput gajah dan rumput-rumputan lain dan diberi air garam serta konsentrat. Semua peternak tidak mengukur banyaknya pakan yang diberikan.

Peternak di Kecamatan Mamasa belum memperhatikan jumlah dan kebutuhan zat-zat gizi dalam makanannya. Mereka hanya memberikan jenis rumput gajah yang dicampur air garam dan kurang memberikan makanan tambahan yang dapat memenuhi kebutuhan gizi pada ternak. Dengan kata lain bahwa dalam sistem pemeliharaan ternak kerbau belang di Kecamatan Mamasa, peternak belum memperhatikan faktor makanan. Muliasno (2009) menyatakan bahwa untuk meningkatkan produksi serta 
produktivitas ternak, peternak harus terampil dalam mengelola usahanya, terutama dalam penyediaan pakan, karena pakan merupakan kunci utama keberhasilan usaha peternakan, baik pakan hijauan berupa rumputrumputan maupun pakan tambahan lainnya.

\section{Perkandangan}

Data hasil penelitian mengenai system perkandangan pada kerbau belang di Kecamatan Mamasa ditunjukkan pada tabel berikut.

Tabel 5. Sistem Perkandangan Ternak Kerbau Belang di Kecamatan Mamasa.

\begin{tabular}{|c|c|c|c|}
\hline No. & Uraian & $\begin{array}{c}\text { Jumlah } \\
\text { Responden }\end{array}$ & Persentase \\
\hline \multirow[t]{6}{*}{1.} & Sistem perkandangan: & & \\
\hline & - Ternak dikandangkan terus menerus & 0 & 0 \\
\hline & - Ternak dikandangkan pada malam hari saja & 7 & 30,4 \\
\hline & - Ternak diikat di samping rumah & 0 & 0 \\
\hline & - Kadang dikandangkan dan kadang dilepas & 2 & 8,7 \\
\hline & - $\quad$ Tidak ada kandang & 14 & 60,9 \\
\hline \multirow[t]{6}{*}{2.} & Keadaan kandang (bentuk dan bahan kandang): & & \\
\hline & $\begin{array}{l}\text { - Bangunan kandang terbuat dari bahan-bahan } \\
\text { setempat }\end{array}$ & 14 & 60,9 \\
\hline & - Bangunan kandang sebagian dibeli & 0 & 0 \\
\hline & - Bangunan kandang terbuat dari beton & 0 & 0 \\
\hline & $\begin{array}{l}\text { - Bangunan kandang terbuat dari kayu dan } \\
\text { bambu dengan atap seng }\end{array}$ & 2 & 8,7 \\
\hline & $\begin{array}{l}\text { - Kandang terbuat dari kayu dan bambu, lantai } \\
\text { beton dengan atap seng }\end{array}$ & 7 & 30,4 \\
\hline \multirow[t]{5}{*}{3.} & Pemakaian kandang: & & \\
\hline & - Jantan dan betina dipisahkan & 4 & 17,4 \\
\hline & - Jantan dan betina disatukan & 14 & 60,9 \\
\hline & - Hanya ternak jantan & 5 & 21,7 \\
\hline & - Habya ternak betina & 0 & 0 \\
\hline \multirow[t]{5}{*}{4.} & Perlengkapan kandang: & & \\
\hline & $\begin{array}{l}\text { - Kandang dilengkapi dengan fasilitas yang } \\
\text { lengkap (tempat makan, tempat minum, } \\
\text { saluran pembuangan kotoran dll). }\end{array}$ & 0 & 0 \\
\hline & - Disediakan seadanya & 0 & 0 \\
\hline & - Hanya tempat makan dan minum & 4 & 17,4 \\
\hline & - Tidak ada perlengkapan kandang & 19 & 82,6 \\
\hline \multirow[t]{5}{*}{5.} & Sanitasi kandang: & & \\
\hline & - Kandang selalu dibersihkan & 4 & 17,4 \\
\hline & - Kadang-kadang dibersihkan & 19 & 82,6 \\
\hline & - Dibersihkan kalau terserang penyakit & 0 & 0 \\
\hline & - $\quad$ Tidak pernah dibersihkan & 0 & 0 \\
\hline
\end{tabular}


Sistem perkandangan yang dilakukan oleh peternak yaitu ternak dikandangkan hanya pada malam hari saja $(30,4 \%)$, sedangkan yang dilepas pada saat tertentu sebesar $8,7 \%$. Kandang berbentuk pagar yang terbuat dari kayu dan bambu sebesar $60,9 \%$, peternak yang bangunan kandangnya terbuat dari kayu dan bambu serta lantai beton dengan atap seng sebesar $30,4 \%$. Penggunaan kandang dengan menyatukan ternak sebesar $60,9 \%$, sedangkan yang mengkandangkan hanya ternak jantan saja sebesar $21,7 \%$, ternak jantan dan betina yang dipisahkan dalam kandang sebesar 17,4\%. Dari segi perlengkapan kndang, sebesar $82,6 \%$ peternak tidak menyediakan perlengkapan kandangnya, oleh karena adanya perlakuan khusus yang dilakukan peternak seperti menggantung makanan sebatas tinggi ternak, dengan tujuan agar leher ternak menjadi besar, kokoh dan kuat. Demikian halnya dengan kandang yang dilengkapi dengan tempat makan dan minum, sebanyak $17,4 \%$ peternak membuat agak tinggi. Soal sanitasi, kandang yang selalu dibersihkan, persentase peternak sangat rendah yaitu sebesar $17,4 \%$ dibandingkan dengan yang selalu membersihkan kandang sebesar $82,6 \%$ peternak.Berdasarkan data penelitian ini, menunjukkan bahwa peternak umumnya mempergunakan bahan-bahan setempat seperti kayu dan bambu dalam pembuatan kandang.

Manajemen perkandangan ternak yang baik dan berkualitas akan memebrikan keuntungan yang baik dan besar bagi peternak sehingga memudahkan dalam mengawasi, pemberian pakan, pencegahan dan pengobatan penyakit serta ternak terhindar dari terik matahari dan predator (Muliasno, 2009).

\section{Pengontrolan Penyakit.}

Data pengontrolan penyakit pada usaha ternak kerbau belang dari peternak di Kecamatan Mamasa dapat dilihat pada Tabel 6.Persentase pengontrolan penyakit menunjukkan bahwa responden yang mengontrol penyakit setiap saat sebesar $69,6 \%$, dikontrol saat ternak sakit sebanyak $17,4 \%$, sedangkan kadang-kadang mengontrol sebesar 13,0\%. Pencegahan penyakit yang dilakukan saat tertentu sebesar $21,7 \%$. Tindakan pengobatan penyakit yang dilakukan oleh peternak dan oleh petugas Dinas Peternakan sebesar 39,1\%, yang dilakukan oleh petugas Dinas Peternakan sebanyak $34,8 \%$, dan yang dilakukan oleh peternak sendiri sebesar $26,1 \%$ disbanding peternak yang memperoleh obat-obatan dari dinas Peternakan, $8,7 \%$ peternak membuat sendiri obat-obatannya. Menurut Subronto (1985), dalam pengelolaan peternakan harus lebih mengutamakan usaha pencegahan, sanitasi kandang serta perlindungan ternak dari penyakit-penyakit yang dapat mengakibatkan kerugian besar bagi peternak.

\section{Reproduksi}

Pengamatan keadaan reproduksi ternak kerbau belang tiao oeternak di Kecmaatan Mamasa ditunjukkan pda Tabel 7. 


\section{Tabel 6. Pengontrolan Penyakit pada Usaha Ternak Kerbau Belang di Kecamatan Mamasa.}

\begin{tabular}{|c|c|c|c|}
\hline No. & Uraian & $\begin{array}{c}\text { Jumlah } \\
\text { Responden }\end{array}$ & Persentase \\
\hline \multirow[t]{5}{*}{1.} & Sistem pengontrolan penyakit: & & \\
\hline & - Dikontrol setiap saat & 16 & 69,6 \\
\hline & - $\quad$ Kadang-kadang dikontrol & 3 & 13,0 \\
\hline & - Dikontrol apabila ternak sakit & 4 & 17,4 \\
\hline & - Tidak pernah dikontrol & 0 & 0 \\
\hline \multirow[t]{5}{*}{2.} & Tindakan pencegahan penyakit: & & \\
\hline & $\begin{array}{l}\text { - Pencegahan dilakukan rutin oleh petugas Dinas } \\
\text { Peternakan }\end{array}$ & 0 & 0 \\
\hline & - Dilakukan oleh petugas dan peternaksaat tertentu & 5 & 21,7 \\
\hline & - Dilakukan oleh peternak & 18 & 78,3 \\
\hline & - Tidak dilakukan pencegahan & 0 & 0 \\
\hline \multirow[t]{5}{*}{3.} & Tindakan pengobatan penyakit: & & \\
\hline & - Dilakukan oleh petugas Dinas Peternakan & 8 & 34,8 \\
\hline & $\begin{array}{l}\text { - Dilakukan oleh petugas peternak dengan obat } \\
\text { tradisional }\end{array}$ & 6 & 26,1 \\
\hline & $\begin{array}{l}\text { - Dilakukan oleh petugas Dinas Peternakan dan } \\
\text { peternak }\end{array}$ & 9 & 39,1 \\
\hline & - Tidak dilakukan pengobatan & 0 & 0 \\
\hline \multirow[t]{5}{*}{4.} & Cara memperoleh obat-obatan: & & \\
\hline & - Dari Dinas Peternakan & 9 & 39,1 \\
\hline & - $\quad$ Membeli sendiri & 12 & 52,2 \\
\hline & - Dibuat sendiri & 2 & 8,7 \\
\hline & - Diperoleh dari sesama peternak & 0 & 0 \\
\hline
\end{tabular}

Hasil pengamatan di lapangan menunjukkan bahwa persentase peternak yang mengawinkan ternak dengan cara system perkawinan alamiah (tidak ada campur tangan manusia) mencapai $100 \%$. Umur pertama ternak jantan dikawinkan berturut-turut pada umur 3 tahun sebesar 78,3\%, umur 3,5 tahun dan umur 2 tahun sama yaitu sebanyak
8,7\%, dan umur 4 tahun sebesar 4,3\%. Demikian halnya dengan ternak betina. Semua peternak mengetahui tanda-tanda ternak betina sudah dapat dikawinkan setelah melihat tandatanda birahi. Dilihat dari pemahaman peternak dalam melihat tanda-tanda ternak siap dikawinkan, ternyata sebagian besar peternak mengetahui dan memahami faktor reproduksi. 
Tabel 7. Keadaan Reproduksi Ternak Kerbau Belang di Kecamatan Mamasa.

\begin{tabular}{|c|c|c|c|}
\hline No. & Uraian & $\begin{array}{c}\text { Jumlah } \\
\text { Responden }\end{array}$ & Persentase \\
\hline \multirow[t]{5}{*}{1.} & Sistem perkawinan: & & \\
\hline & - Dalam kandang (ada campur tangan manusia) & 0 & 0 \\
\hline & - Dilepas (kawin alamiah) & 23 & 100 \\
\hline & - Dilakukan kawin suntik (IB) & 0 & 0 \\
\hline & - $\quad$ Tidak diperhatikan & 0 & 0 \\
\hline \multirow[t]{7}{*}{2.} & Umur pertama dikawinkan (jantan): & & \\
\hline & - Kawin pertama di atas 2 tahun & 2 & 8,7 \\
\hline & - Kawin pertama umur 3 tahun & 18 & 78,3 \\
\hline & - $\quad$ Umur 3,5 tahun & 2 & 8,7 \\
\hline & - Umur 4 tahun & 1 & 4,3 \\
\hline & - Dikawinkan saat birahi pertama & 0 & 0 \\
\hline & - $\quad$ Tidak tahu & 0 & 0 \\
\hline \multirow[t]{7}{*}{3.} & Umur pertama dikawinkan (betina): & & \\
\hline & - $\quad$ Umur 2,5 tahun & 2 & 8,7 \\
\hline & - $\quad$ Umur 3 tahun & 18 & 78,3 \\
\hline & - $\quad$ Umur 3,5 tahun & 2 & 8,7 \\
\hline & - Umur 4 tahun & 1 & 4,3 \\
\hline & - Dikawinkan saat ternak birahi & 0 & 0 \\
\hline & - Tidak tahu & 0 & 0 \\
\hline \multirow[t]{4}{*}{4.} & $\begin{array}{l}\text { Bagaimana peternak mengetahui tanda-tanda } \\
\text { ternak betina sudah dapat dikawinkan: }\end{array}$ & & \\
\hline & $\begin{array}{l}\text { - Dikawinkan setelah melihat tanda-tanda birahi } \\
\text { pada ternak }\end{array}$ & 23 & 100 \\
\hline & $\begin{array}{l}\text { - Dikawinkan begitu saja tanpa melihat tanda- } \\
\text { tanda birahi }\end{array}$ & 0 & 0 \\
\hline & - Tidak tahu & 0 & 0 \\
\hline \multirow[t]{4}{*}{5.} & $\begin{array}{l}\text { Tanda-tanda ternak birahi: } \\
\text { - Nafsu makan menurun, vulva membengkak, } \\
\text { sering menaiki sesame, kelihatan gelisah, } \\
\text { keluar lender putih }\end{array}$ & 16 & 69,6 \\
\hline & $\begin{array}{l}\text { Keluar lender putih dari vulva, sering menaiki } \\
\text { sesame }\end{array}$ & 7 & 30,4 \\
\hline & - Nafsu makan menurun, kelihatan gelisah & 0 & 0 \\
\hline & - Tidak tahu tanda-tanda birahi & 0 & 0 \\
\hline
\end{tabular}

\section{KESIMPULAN}

Peternak kerbau belang di Kecamatan Mamasa menerapkan tatalaksana pemeliharaan secara tradisional. Kurangnya pengetahuan serta pemahaman peternak tentang pemeliharaan serta kecintaan mereka terhadap sesuatu yang berharga menghalangi perubahan sikap peternak terhadap pengetahuan peternakan yang baik. 


\section{SARAN}

1. Perlu adanya perbaikan tatalaksana pemeliharaan ternak kerbau belang yang ada di Kecamatan mamasa

2. Perlu adanya kegiatan penyuluhan, pelatihan atau pembinaan dari instansi terkait yang berkesinambungan, sehingga pengetahuan dan keterampilan dari peternak akan lebih baik.

3. Adanya kesadaran, rasa kecintaan dan memiliki sesuatu yang berharga, sehingga peternak mau merubah sikap, dalam hal penerapan tatalaksana yang baik (intensif).

4. Perlu adanya penelitian terhadap kepercayaan masyarakat setempat tentang adanya tempat-tempat khusus kerbau belang dapat lahir, sehingga produktivitas dapat ditingkatkan.

\section{DAFTAR PUSTAKA}

Anggorodi, R. 1994. Ilmu Makanan Ternak Umum. PT. Gramedia Pustaka Utama. Jakarta.

Anonimous. 2010. Kerbau. Wikipedia bahasa Indonesia. http://wikipedia.org/wiki/kerbau. com

Anonimous. 2009. Kabupaten Mamasa dalam Angka. Badan Pusat Statistik Kabupaten Mamasa.

Anonimous. 1973. Ternak Umum. Yayasan Aksi Agraris Kanisius. Yogyakarta.

Apriantono, A. 2008.Pedoman pembibitan kerbau yang baik.www.pdfsearch.org/tscr/ter nak-kerbau.com

Arikunto, S. 1992. Prosedur Penelitian. PT. Rineka Cipta. Jakarta.

Kusumanto, D. 2009.Sistem kandang Ngebrok untuk ternak kerbau di Krayan.www.sistem-kandangngebrok-untuk-ternak.html.com

Matandung, R., B. Marimbunan, dan T. Pawan. 2007. Kearifan lokal menjaga kesehatan kerbau belang. www.pewartakabaraindonesia.b logspot.com

Muliasno, S. 2009. Manajemenisasi peternakan kerbau.www.pewrtakabaranindo nesia.blogspot.com

Singarimbun dan S. Efendi. 1989. Metode Penelitian Survey. PT Pustaka LP3ES. Indonesia. Jakarta.

Subronto. 1985. Ilmu Penyakit Ternak. Gadjah Mada University Press. Yogyakarta.

Syarifuddin, N.A. 2008. Evaluasi Nilai Gizi Pakan Alami Ternak Kerbau Rawa di Kalimantan Selatan.www.mages.andinursya m.multiply.multiplycontent.com

Talib, C. 2008.Kerbau, Ternak Potensial yang Dianaktirikan.www.pustakadept an.go.id.com 
Wodzicka, M. Tomaszewska, I.K.

Sutawa, I.G. Putu, dan T.D.

Caniago. 1991. Reproduksi,

Tingkah Laku, dan Produksi

Ternak di Indonesia. PT.

Gramedia Pustaka Utama.

Jakarta. 